\title{
On the Possibility of Obtaining Geomagnetic Volcanic Records of the Short-Term Behavior of the Laschamp and Pringle Falls Excursions from the Long Sequence of Kahuku and Ninole Hills, Big Island of Hawaii, USA
}

\author{
Emilio Herrero-Bervera (1) \\ Paleomagnetics and Petrofabrics Laboratory, SOEST-Hawaii Institute of Geophysics and Planetology, University of Hawaii at \\ Manoa, Hawaii, USA \\ Email: herrero@soest.hawaii.edu
}

How to cite this paper: Herrero-Bervera, E. (2021) On the Possibility of Obtaining Geomagnetic Volcanic Records of the ShortTerm Behavior of the Laschamp and Pringle Falls Excursions from the Long Sequence of Kahuku and Ninole Hills, Big Island of Hawaii, USA. Open Journal of Geology, 11, 712-733.

https://doi.org/10.4236/ojg.2021.1112035

Received: October 4, 2021

Accepted: December 27, 2021

Published: December 30, 2021

Copyright $\odot 2021$ by author(s) and Scientific Research Publishing Inc. This work is licensed under the Creative Commons Attribution International License (CC BY 4.0).

http://creativecommons.org/licenses/by/4.0/

\begin{abstract}
The Mauna Loa volcano of the Big Island of Hawaii offers the "ad-hoc" lava flows that have recorded the geomagnetic short-term behavior (i.e. excursions) at two key localities such as the younger Kahuku volcanic series (ca. $\sim 41 \mathrm{ka}$ ) where 29 flows are exposed for detailed paleomagnetic sampling making up 102 meters of section where the uppermost flow sampled lies directly under the Pahala ash. The second sampling site is the Ninole volcanic series where 25 flows spanning 56 meters of section were also sampled from the northeast and southwest sides of the Kilohana Ridge. The most recent age estimate indicates that the Kahuku flows can correlate well with the transitional/excursional directional results obtained from both volcanic and deepsea sediments of the global record of the Laschamp (ca. 41 ka calendar years B.P) excursion and the Ninole flows which are associated to the also global Pringle Fall excursion (ca. $211 \pm 13 \mathrm{ka}$ ) recorded at the type section.
\end{abstract}

\section{Keywords}

Ninole Hills, Kahuku Ranch, Mauna Loa Volcano, Laschamp, Pringle Falls Excursion

\section{Introduction}

An improved understanding of the origin of the geomagnetic field, and the process via which it reverses its polarity, is a longstanding goal of in the Earth 
Sciences. One of the means by which this goal can be achieved is to examine in detail the temporal variations in geomagnetic field direction and intensity associated with polarity reversals and short polarity excursions or events. One of the more fruitful recent efforts in this field is the utilization of geodynamo models [1]-[10] to test and refine models for geomagnetic field origin and reversal mechanisms, with comparisons made between spatially and temporally robust sets of full-vector (direction and paleointensity) geomagnetic field data. One consequence of these efforts has been the recognition that there is a need for many high quality records of geomagnetic field behavior from a well-distributed set of site locations for a given time interval of geomagnetic field evolution. In the case of short polarity events or excursions, a number of high quality records of paleomagnetic directions, and absolute paleointensities, from a variety of locations, are needed to gain a full understanding of the origin of these geomagnetic field phenomena, and how their behavior compares to the process by which full reversals of the geomagnetic field occur. Such data could ultimately be used to determine if polarity excursions and reversals are similar geomagnetic field phenomena; excursions being aborted reversals, for example [9] [11] [12] [13]—or are a possible manifestations of a different process [14].

While there are many excellent studies of geomagnetic field polarity reversals [13] [15]-[34] there are only very few full-vector studies of short-lived polarity events or excursions. The majority of such data for excursions are from sedimentary rocks, for which only relative paleointensity values can be inferred. Studies of relative paleointensity derived from sedimentary rocks typically find correlations between relative paleointensity lows and geomagnetic field reversals or excursions [35]-[42]. While of great value, there remains considerable uncertainty in the interpretation of relative paleointensity data from sedimentary rocks [43] [44] [45], and because many of these data are obtained from azimuthally-unoriented marine and lacustrine sediment cores, the directional data associated with these records are of relatively uncertain value. An attractive alternative is to obtain directional and paleointensity information from volcanic rocks that have been erupted during polarity excursions. Such volcanic rocks commonly record the geomagnetic field with high fidelity, and the sound theoretical basis for TRM acquisition in these rocks lends to the interpretation of absolute paleointensity data obtained from such igneous rocks [46]. Unfortunately, the stochastic nature of volcanic eruptions and the relatively short duration of the geomagnetic field reversal/event process, combine to make volcanic records of geomagnetic field behavior during reversals or excursions rare. There are relatively few studies that document both directional and paleointensity records from polarity excursions [42] [47]-[53].

Most of these studies document separate excursions (ranging in age from the Eocene to the Pliestocene), so there is clearly a need for additional studies of particular excursions recorded in several widely spaced geographic areas. Of the short polarity excursions, the Blake and Pringle Falls Events are among the better recognized and studied, but they remain somewhat enigmatic. The age of the 
Blake event is generally reported as $110 \mathrm{ka}$ [23] based on studies of sediment cores from many parts of the world. In igneous rocks, partial records of the Blake event (usually a single cooling unit) have been recorded in China [54] and in tephras from Japan [55]. Of these studies, $\mathrm{K} / \mathrm{Ar}$ ages provide age estimates of $123 \pm 7 \mathrm{ka}$ [54] and an older age of $141 \mathrm{ka}$ for the Aso-2 tephra [55]. The nature of the geomagnetic field during the Blake event is complex and somewhat controversial. Some studies have documented two [22] [31] [56] [57] excursion "pulses", spanning 10 - $50 \mathrm{ky}$, while in some sedimentary sequences the Blake event is absent in the directional records, and is at times only manifest by a low in relative paleointensity values (see for example [58]. The Pringle Falls event [40] [57] is now very well dated $(211 \pm 13 \mathrm{ka})$ using ${ }^{40} \mathrm{Ar} /{ }^{39} \mathrm{Ar}$ methods on volcanic rocks [59] - that recorded this event therefore here we present a potential record from lavas at Ninole Hills.

The second record is potentially correlatable with the Laschamp (ca. 41,000 years B.P.) that presumably has been registerd by the Kahuku basalts, Mauna Loa volcano. The main goal of this manuscript is an attempt to establish a possible correlation to the natural remanent magnetization (NRM) results of the declination and inclination records of the Mauna Loa volcano obtained by [60] with the records of the type section of the Pringle Falls excursion at the Deschutes river, Oregon and the directional results of the global Laschamp excursion both from deep-sea sediments and volcanic rocks.

\section{Geology of the Ninole and Kahuku Basalt}

There are two sets of older basalts that are found in the SE portion of Hawai'i; the Ninole Basalts, and the Kahuku Basalts. The Ninole Basalts crop out in several places within the Ninole Hills, on the SE flank of Mauna Loa volcano (Figure 1). The Ninole Hills are a highly dissected portion of Mauna Loa, and have long been considered a local geomorphic anomaly, comprised of some of the oldest rocks on the island of Hawai'i [61].

Older work, such as 72-Stearns and Macdonald (1946) speculated that the Ninole Basalts were the product of an older vent/rift system, separate from Mauna Loa, in this area. Additional recent mapping [62] and geochemistry and geochronology [63] have concluded that the Ninole Basalts represent the remnants of an older phase of Mauna Loa construction, part of which subsequently collapsed via a large gravitational slide, at ca 90 - $100 \mathrm{ka}$ [64] [65]. The Kahuku Basalts occur in three areas; a thin strip of flows at Kahuku Pali, south of the town of Kahuku and extending to the southernmost coast of Hawai'i, a thin coastal outcrop belt at Maniania Pali on the SE coast, and an outcrop belt of flows near Waiohinu (Figure 1). The age of the Ninole Basalt is based on K-Ar data from [63] with samples collected from Makanau Hill, Pu'u Enuhe, and Hilea Gulch. Although complicated by some alteration, and low K values, [63] obtained an age of $120 \pm 28 \mathrm{ka}$ for 3 samples in the middle portion of the Ninole section, and concluded that an age range from 100 to $200 \mathrm{ka}$ is the best estimate for the age of these rocks, with an upper limit of perhaps $0.3 \mathrm{Ma}$ [63]. It should 

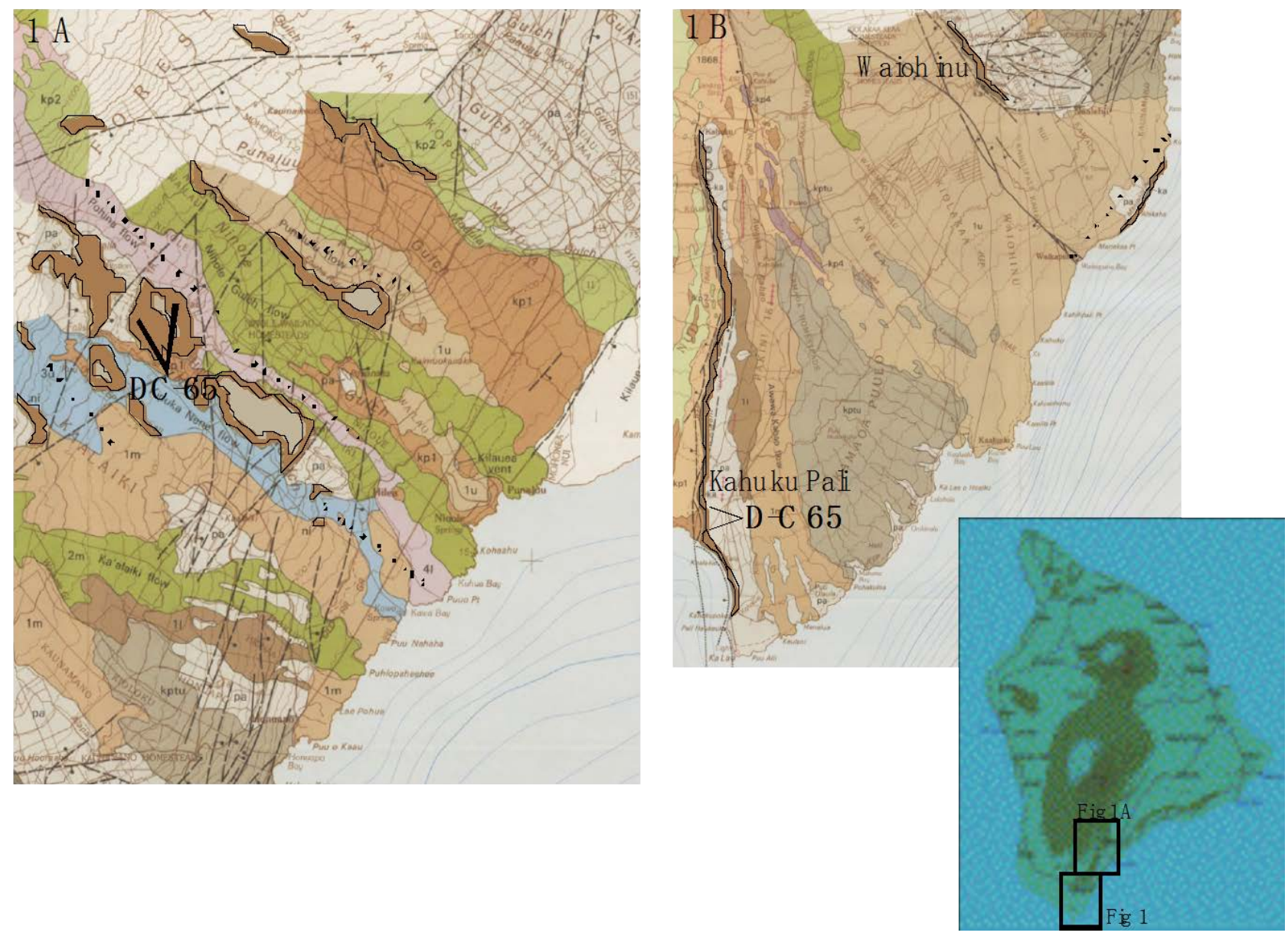

Figure 1. Geological Map of SE portion of Mauna Loa, Hawai'i, modified from Lipman and Swenson, 1984. 1(A) Ninole Area; outcrops of the 100 to 300 ka Ninole Basalt are highlighted. DC-65 notes the section on the NE and SW slopes of Kaiholena Ridge that were sampled [60]; other areas noted are proposed sample collection areas described in the proposal. 1(B) Kahuku/South Point area; outcrops of the $>31$ ka Kahuku Basalt are highlighted. DC-65 notes the area on Kahuku Pali sampled by Doell and Cox, 1965 [60].

also be noted that, based on similar problems with age determinations from other Hawai'ian basalts, these ages were considered by [64] to represent minimum ages. [64] reports attempt to determine the age of the Kahuku Basalts using K-Ar; these results were inconclusive (41 \pm 65 and $37 \pm 62$ ka for two samples from a single flow collected at Kahuku Pali).

The Ninole Basalts are thin flows of pahoehoe and aa, with occasional interspersed basaltic tuff layers, and are generally a light grey in color [63]. These basalts underlie the $\sim 30 \mathrm{ka}$ Pahala Ash, and are exposed over an elevation range of $\sim 600$ meters. The base of the Ninole Basalt is not exposed, so their total thickness is unknown. Outcrops of Ninole Basalt form steeply-sloped hills in the area. These hills are surrounded in many places by younger (post Pahala Ash) Mauna Loa flows of Kau Basalt. The Ninole Basalt is variably weathered and in most places is poorly exposed, but good exposures (sometimes requiring some machete work) can be found in road cuts and in portions of the dry stream beds of the Hilea Gulch. The newer ${ }^{40} \mathrm{Ar} /{ }^{39} \mathrm{Ar}$ results constrain the eruption of the Ninole 
Basalts from 227 to $108 \mathrm{ka}$ providing maximum estimates on the timing of the Ka Lae and South Kona landslides [66].

The Kahuku Basalt is chemically and texturally similar to the younger Kau Basalt, and is exposed over a $\sim 200 \mathrm{~m}$ elevation range. The statigraphic relationship between these two units is unclear; 74-Lipman et al., 1990 have suggested that the Kahuku and Ninole Basalts may be similar or coeval in age. Other workers [60] have suggested that the Kahuku Basalt may be somewhat younger than the Ninole Basalt. [63] that further mapping and geochemical analyses of these basalts are needed in order to fully resolve the stratigraphy of these basalts, and their relationship to other Mauna Loa flows. A most ${ }^{40} \mathrm{Ar} /{ }^{39} \mathrm{Ar}$ radiometric age has been determined from the Mauna Loa volcano from the Kahuku landslide scarp cutting Mauna Loa's submarine southwest rift zone, and from lavas in a deeper section of the rift.

\section{The Pringle Falls Lacustrine Geomagnetic Record}

The original record of the Pringle Falls excursion at the sedimentary lake sequence sampled originally by [56] [57] as well as well as the subsequent re-visited sites sampled for this study, including the two additional profiles [40], that are part of an extensive pre-historic fluvial and lacustrine system formed during the last million years located east of the Cascade mountains.

The discovery of the Pringle Falls took place in the late ' 80 s and at the beginning of the identification of the excursion research it was mistakenly identified as the Blake polarity episode [56] [57]. It was after the identification of the characteristic geomagnetic features recorded by the declination and inclination records and the research work done about the chronostratigraphy, geochronology and tephrachronology that documented two sites at Pringle Falls along the Deschutes river in Oregon (see Figure 2) that the excursion was officially described and established as a geomagnetic feature [57]. Subsequent research work was performed to correlate the directional geomagnetic signal from additional profiles drilled ( $~ 837$ samples) along the Deschutes river spaced along $5 \mathrm{kms}$ for their detailed directional geomagnetic signature. Thus far, the rock magnetic characterization as well as the entire directional analyses (i.e. declination and inclination) of the geomagnetic paleosignal of four widely spaced profiles has been completed and published recently [40] [67].

There is a published record of the Pringle Falls "aborted reversal" that has been dated by means of ${ }^{40} \mathrm{Ar} /{ }^{39} \mathrm{Ar}$ yielding an age of $211 \pm 13 \mathrm{ka}$ [57] and correlated along a $5 \mathrm{~km}$ segment in the Deschutes river in Oregon. A full vector description of the excursion by means of directions [40] Relative Paleointensity (RPI) measurements that will be part of the geomagnetic polarity time global scale [67] have been published as well.

\section{Summary of the Directional Results (i.e. Declination and Inclination)}

The rock magnetic tests performed on the Pringle Falls samples such as rema- 
nent magnetization of the four profiles show an excellent magnetostratigraphic correlation of the main excursional features labeled as A, B and C present on the four records shown in Figure 2 and have been published relatively recently [40]. The directional results have been converted to virtual geomagnetic poles

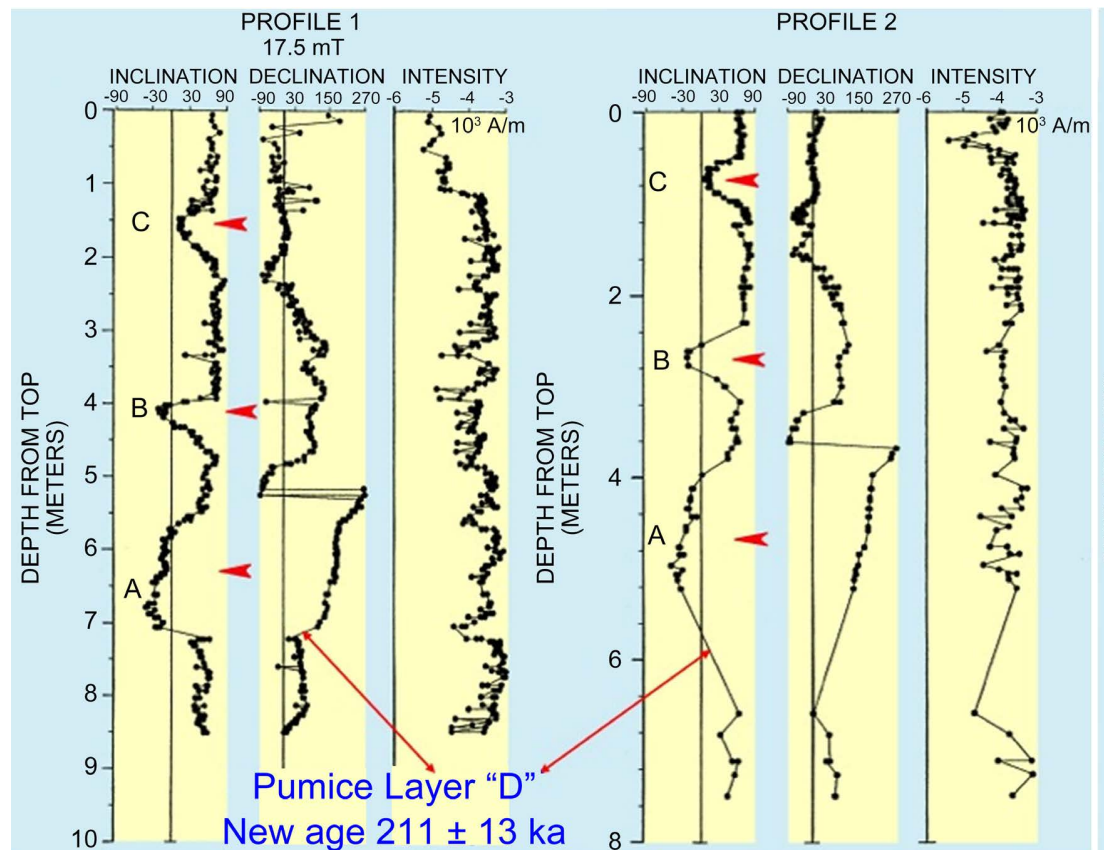

PROFILE 2

PROFILE 3
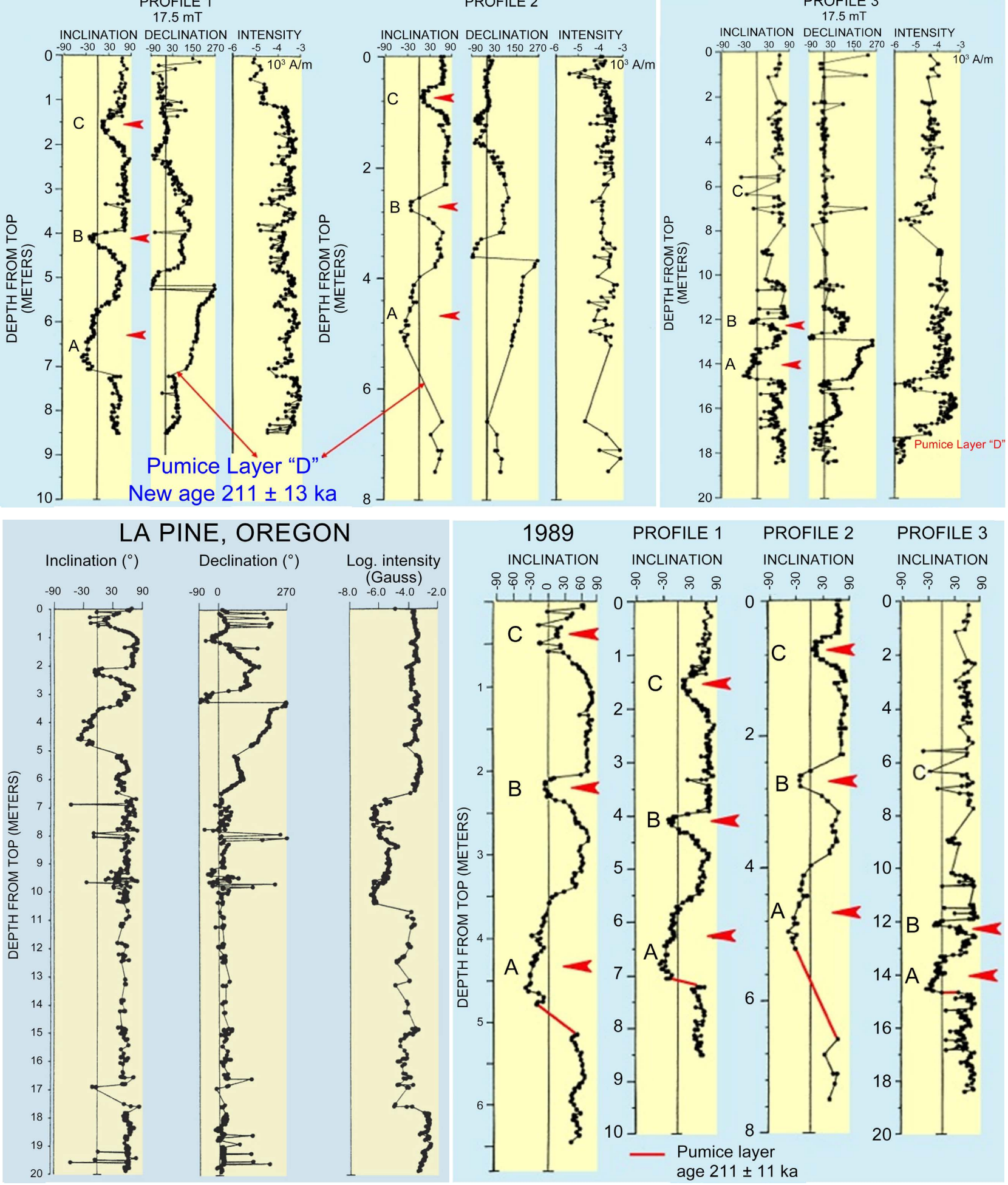

(a) 


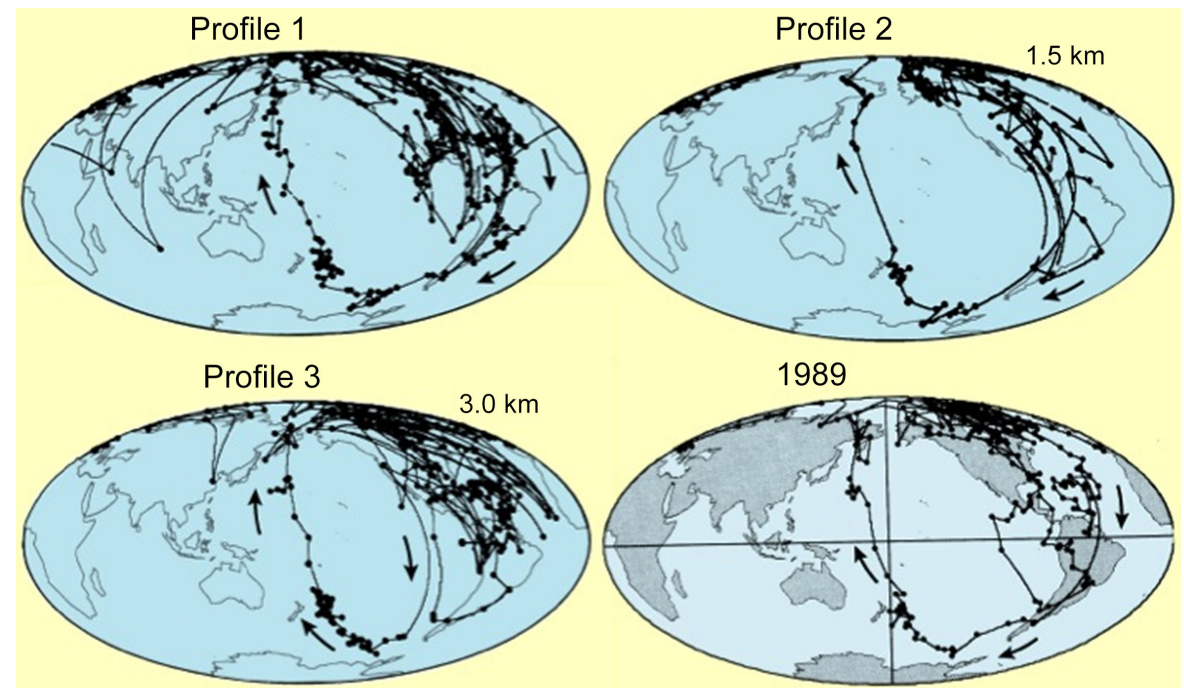

(b)
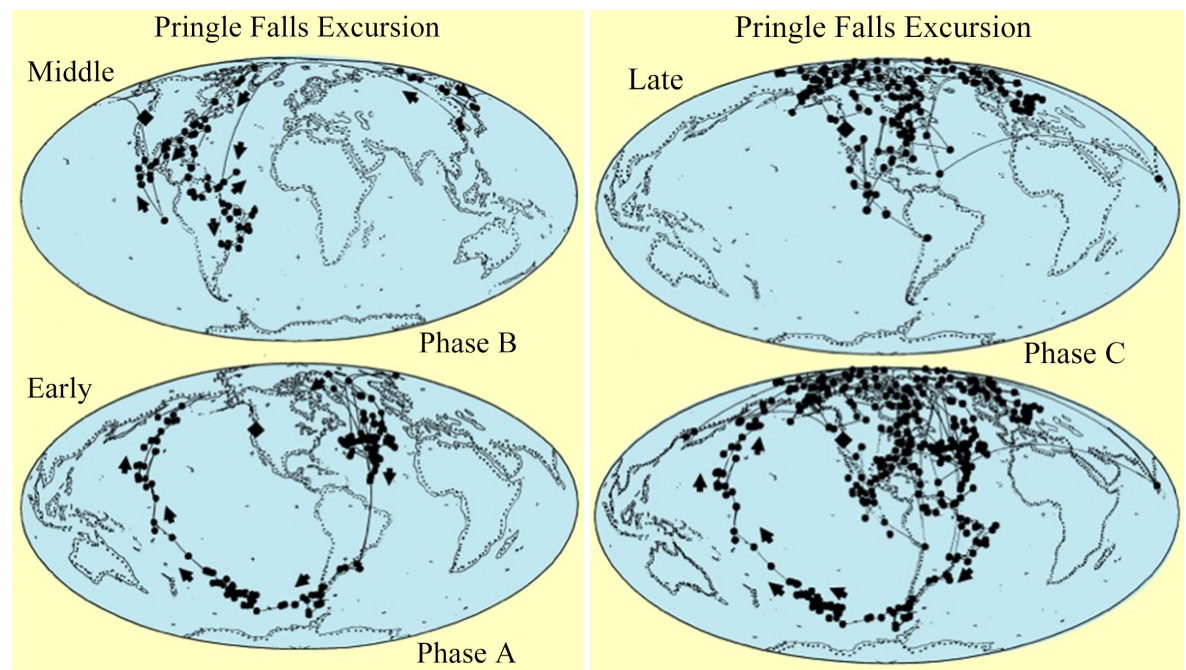

(c)

Figure 2. (a) Magnetostratigraphic correlation of the directional (i.e. declination, inclination and intensity of magnetization) behavior of four profiles recorded at the Pringle Falls site, Oregon. The red arrows show the characteristic inclination geomagnetic features A, B and C of the Pringle Falls excursion [40]. (b) Virtual Geomagnetic Pole paths of four widely separated profiles recovered from the type locality of Pringle Falls Oregon (c) Virtual Geomagnetic Poles (VGPs) of the Pringle Falls excursion showing the "geomagnetic signature" that characterize the excursion at Pringle Falls, Oregon [40].

(VGP's) in order to compare the excursional characteristics of the profiles. Figure 2 shows the characteristic geomagnetic signature of the excursion and the results of only one site are displayed as "snap shots" of the aborted reversal paths as an initial/oldest and early phase corresponding to the geomagnetic feature " $A$ " (see Figure 2(a)) and the subsequent intermediate middle phase " $B$ " and the final and youngest phase " $\mathrm{C}$ ". The arrows indicate the motion of the individual VGPs along the excursional paths showing the characteristic loops that define the unique geomagnetic signature of the Pringle Falls excursion at the type section. In order to prove that the VGP magnetic signature has been recorded by the four sites Figure 2(b) shows the paths derived from the individual profiles 
and the intrabasinal correlation of the signature. As a result of the VGP correlation paths one can conclude that the paths are highly internally correlated, consistent showing very distinct clockwise loops traveling from high northern latitudes over the eastern part of the North American continent and the North Atlantic to South America with a fast motion to high southern latitudes and a subsequent return to high northern latitudes across the Pacific and over Kamchatka associated with the initial phase of the excursion, which corresponds to geomagnetic feature A (Figure 2(c)). The other two geomagnetic features, such as $\mathrm{B}$ and $C$, (Figure 2(c)) corresponding to the middle and late stages of the evolution of the excursional field, have their own looping indicating a complex nondipolar behavior of the excursional field [40].

\section{The Global Excursion of Laschamp (ca. 41 ka B.P.)}

As commented and published recently by [68] Channell et al. (2020) the most thoroughly documented magnetic excursion is undoubtedly the Laschamp excursion at $\sim 41 \mathrm{ka}$ with aberrant magnetic directions that have sub-millennial duration (see reviews of [69] and [70]). Volcanic rocks close to the village of Laschamps in the Chaîne des Puys region of the Massif Central (France) provided the first credible record of any excursion [71], supported by subsequent studies in the same region (e.g., [50] [69] [72] [73] [74]. [70] reviewed volcanic records of the Laschamp excursion that are known from the Olby, La Louchadiere, and Laschamp basalt flows in Chaine des Puys, as well as the ocurrences in New Zealand in the McLennan's Hill basalt flow of the Auckland Volcanic Field and from Mt. Ruapehu [75]. The excursion may be manifest in Hawaiian lavas ([76] although these lavas have not yielded precise ages using ${ }^{40} \mathrm{Ar} /{ }^{39} \mathrm{Ar}$ or other methods. More recently, the excursion has been recorded in sediments from Lake Pupuke, New Zealand [76] and Lake Van, Turkey [77]. Marine records of the Laschamp excursion are numerous (Figure 3). There are now at least a dozen sedimentary records of Laschamp from the North Atlantic (e.g., [78]-[85]), in addition to records from the Gulf of Mexico [79] the Black Sea [86], the equatorial western Pacific ([87] Yamazaki and Ioka, 1994; [88]). These occurrences are supported by a handful of sites in the southern oceans including records off southern Chile [34] [89], from the South Atlantic [90] [91] [92] and from the southern Indian Ocean [93]. Some records of the Laschamp excursion are tied to ice-core chronologies indicating that the excursion correlates to Greenland Stadial (GS) 10 at 41 ka with an estimated duration of less than 1 kyr ([78] [89] [91]. The volcanic records of the Laschamp from Chaîne des Puys and the Auckland Volcanic field allow the integration of ${ }^{40} \mathrm{Ar} /{ }^{39} \mathrm{Ar}, \mathrm{K}-\mathrm{Ar}$, and UeTh dating results [69] [73] [74] to yield a weighted mean age of $40.7 \pm 0.9 \mathrm{ka}$ [70]. Several dozen sedimentary records of the Laschamp excursion place the excursion at $\sim 41 \mathrm{ka}$, and the record in a speleothem from Missouri dated using UeTh methods yielded an age span of $42.25 \mathrm{e} 39.70 \mathrm{ka}$ for the directional excursion with the main phase at $41.10 \pm 0.35 \mathrm{ka}$ [94]. Available records provide an unequivocal 
case for the existence of the Laschamp excursion at $\sim 41$ ka with a duration $<1$ kyr [68].
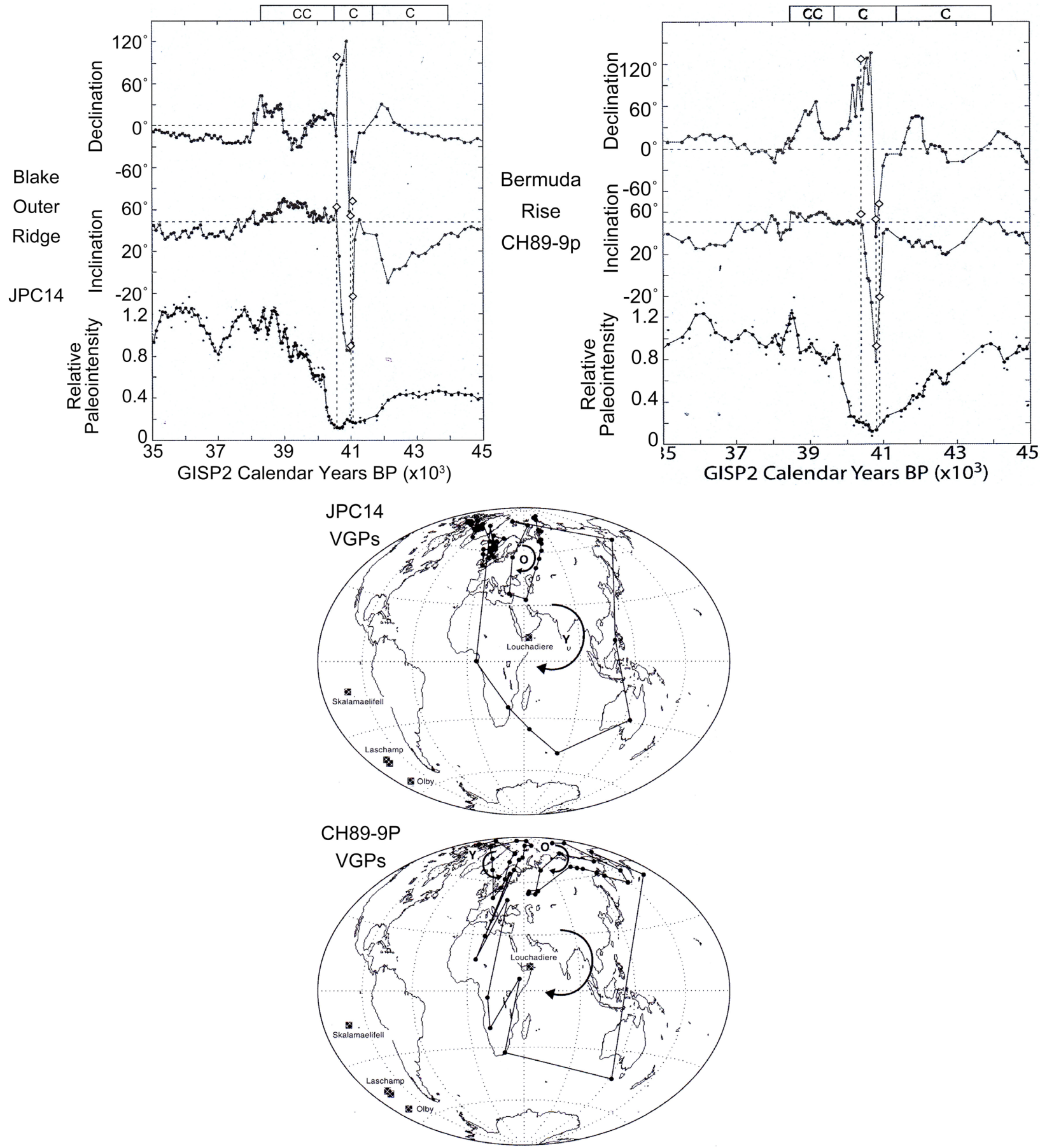

Figure 3. Left diagram shows the paleomagnetic secular variation and relative paleointensity (small dots are original data, large dots are 3-point running average) records from Blake Outer Ridge core JPC14 for the time interval of the Laschamp excursion (upper left diagram) and from the Bermuda Rise core CH89-9P for the same time interval of the Laschamp excursion. Notice the very distinctive declination, inclination and relative paleointensity (RPI) geomagnetic figures at about $\sim 41,000$ years B.P. that characterize the Laschamp excursion. Right side diagram shows the virtual geomagnetic (VGP) paths associated with the Laschamp excursion records from JPV14 and CH89-9P. The individual VGPs of the European Laschamp excursion lavas are shown for comparison. Taken from [81]. 


\section{Ninole Hills experimental paleomagnetic results \\ Prior and Preliminary Paleomagnetic Data}

[60] reported a set of paleomagnetic and rock magnetic results from portions of both the Ninole and Kahuku Basalt sections. For the Ninole Basalts a section of 25 flows (56 m of section) were sampled on the NE and SW slopes of Kaiholena Ridge (Figure 1(A)). For the Kahuku Basalts 29 flows (100 m of section) were sampled at Kahuku Pali (Figure 1(B)). For all sites 4 to 10 oriented samples were collected. They performed step-wise alternating field demagnetization experiments on a subset of samples, using demagnetization steps of 2.5, 5, 10, 20, 40 , and $80 \mathrm{mT}$, in order to evaluate the "magnetic stability" of these rocks. Although their demagnetization experiments indicated significant loss of NRM intensity (median destructive fields from their data range from 20 to $>40 \mathrm{mT}$ ), [60] found that no significant change in directions or scatter of site mean direction occurred following demagnetization, and so they reported mean directions for each flow based on the NRM directions.

Site mean inclinations of the Ninole and Kahuku Basalts, as a function of position in stratigraphic section (Figure 4) have several intervals of either shallow negative or shallow positive inclinations. Poles calculated from the shallow-inclination flows have VGP latitudes of $\sim 65$, and although are not fully reversed are consistent with excursions or events. Based on the age of the Ninole Basalts [63], the negative-inclinations between 10 and $20 \mathrm{~m}$ in the [60] section may be a record of the Blake Event. The set of shallow inclinations found between 10 and 35 meters in the Kahuku Basalts may also represent the Blake Event (if the Ninole and Kahuku Basalts are coeval), or this interval could possibly (based on its position immediately below the $31 \mathrm{ka}$ Pahala Ash) correspond to the Laschamp Event. Alternatively, if the ages of these rocks are on the older end of their inferred age, one or more of these excursions may be related to the Pringle Falls [59].

The data from the Ninole and Kahuku Basalts are similar to the shallow inclinations obtained from 0 - 400 ka rocks sampled in the HSDP hole [95] [96]. Both [95] for three polarity events in the 0 - 400 ka portion of the HSDP pilot hole; the A-associated with the Laschamp, B-associated with the Blake, and $\mathrm{C}$-associated with the Pringle Falls (see Figure 3 of the HSDP publication in [95]). [96] obtained paleointensity data from the same drill core samples; however due to constraints on the available material were unable to work with any samples from excursion B (Blake); they did find lower paleointensity values associated with the single flows that record excursions A (Lachamp) and C (Pringle Falls). Due to the unoriented nature of these cores (and the lack of samples from excursion B for paleointensity work), a full-vector record of these polarity events is not possible. Therefore, although the detailed paleomagnetic, rock magnetic, and paleointensity results from the HSDP holes ([95] [96]) form a valuable set of geomagnetic field data, the simple fact that these samples are azimuthally unoriented makes their significance of somewhat lesser value, especially for assessing VGP behavior associated with polarity transitions or events (Figure 5). 


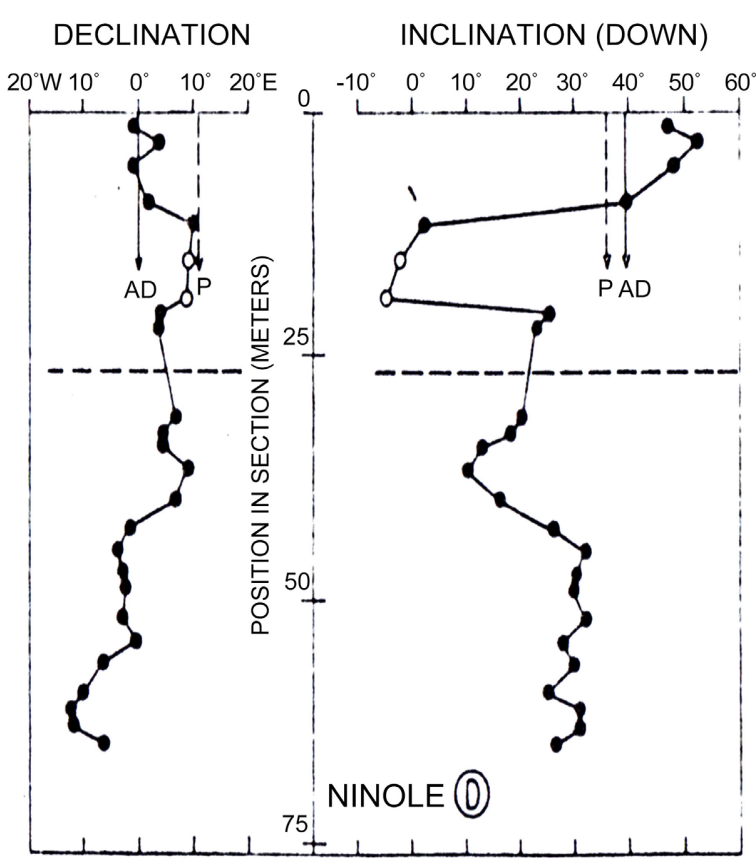

DECLINATION
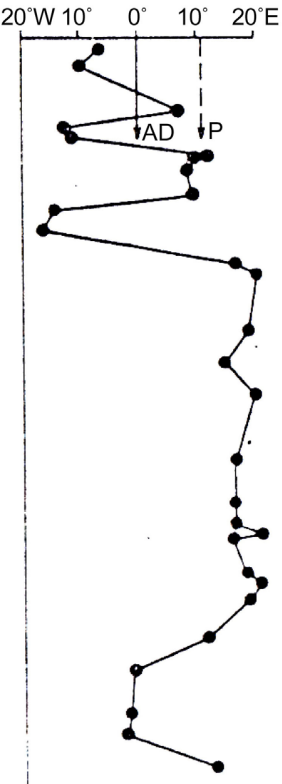

INCLINATION (DOWN)

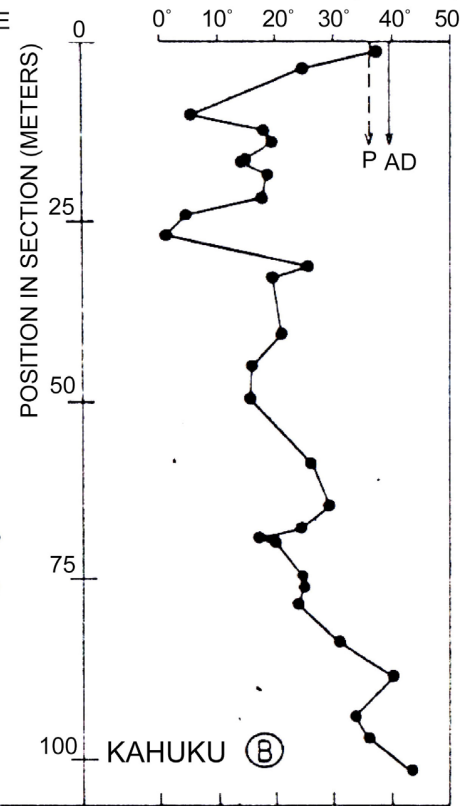

Figure 4. Declination and Inclination versus stratigraphic positions for lavas of the Ninole and Kahuku volcanic series. AD is the axial dipole field values and $\mathrm{P}$, present (inclined dipole) field values Taken from [70].

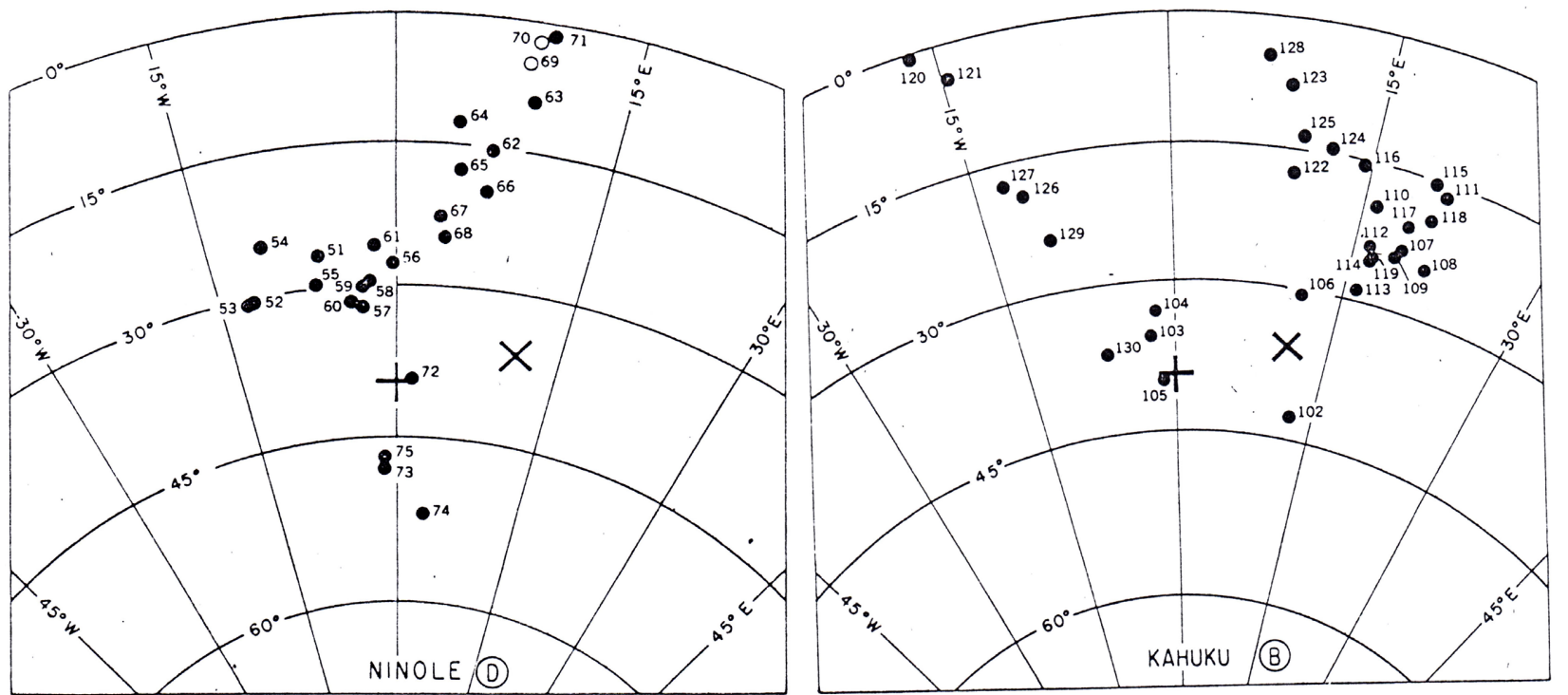

Figure 5. Site mean NRM inclinations, vs. depth below top of sampled sections, for Ninole Basalt (left plot) and Kahuku Basalt (right plot), from Doell and Cox, 1965. The top of the Ninole section is at an unknown (but stratigraphically short, based on map relationships) level below the Pahala Ash. The top of the Kahuku Basalt section occurs immediately below the Pahala Ash. Note the shallow, and upward, inclinations in the Ninole Basalt, and the very shallow inclinations in the Kahuku Basalts. For each site, 4 - 10 samples were measured [60].

Available rock magnetic data for the Ninole and Kahuku Basalts include thermomagnetic (moment vs. temperature) experiments from [60].

Most samples from the Ninole (7/13 flows) and Kahuku (8/12 flows) Basalts had reversible heating and cooling results, with single inflection points, indicating Curie temperatures between $500^{\circ} \mathrm{C}$ and $550^{\circ} \mathrm{C}$. They interpreted these data 
to indicate the presence of low-Ti magnetite as the primary magnetic minerals in these samples. Other Ninole and Kahuku samples had either distributed thermomagnetic curves $(3 / 13$, and $4 / 12)$, or curves that displayed marked irreversibility upon cooling (3/13, and $0 / 12)$.

In order to better understand the suitability of the Ninole and Kahuku Basalts for paleomagnetic and paleointensity experiments, we conducted preliminary field work during March, 2006. Three sites were collected from the Ninole and Kahuku Basalts, with 7 - 10 samples obtained from each site. Access was good for the most part, and a geological reconnaissance of these areas determined that, while in places obscured by heavy vegetation, a great many individual lava flows are available for sampling in these sections. As described in [63], the best outcrops are found along farm access roads that criss-cross the Ninole Hills, and in some dry stream beds. Coastal outcrops of the Kahuku Basalt were also visited, and found to be of good quality for additional paleomagnetic sampling.

Our pilot study samples, measured at both at SOEST-HIGP of the University of Hawai'i, and at Western Washington University, indicate that straight-forward, well-defined magnetization components can be obtained from these rocks using either alternating field or thermal demagnetization (Figure 6). Although no reverse-polarity or transitional directions were obtained by our very limited pilot study, these data do demonstrate that the Ninole and Kahuku Basalts are good recorders of the geomagnetic field, and thus merit further study.

We also conducted some rock-magnetic experiments on these samples, in order to assess their suitability for more detailed paleointensity studies. Although there is no easy method to guarantee the success of these techniques, being able to demonstrate that the rocks in question have a high proportion of single-domain (SD) magnetic grains, and have simple and reversible thermomagnetic behavior does suggest that such samples should be good candidates for further paleointensity studies. Magnetic hysteresis and thermomagnetic curves were determined using the Variable Field Translation Balance (VFTB) at HIGP; or the Vibrating Sample Magnetometer (VSM) at WWU. The hysteresis results are symmetrical (Figure $7(\mathrm{a})$ ), suggesting a simple magnetic mineralogy, and standard hysteresis parameters analyzed using a standard [97] plot indicate that the magnetic domain state is an admixture of SD and larger MD grains, and plots in the PSD field of the Day-type diagram (Figure 7(b)).

Our thermomagnetic experiments, conducted with both the VFTB and VSM, are similar to those reported by [60] Doell and Cox, 1965, for these rocks. Relatively simple, reversible, thermomagnetic curves are obtained for most samples (Figure 8), with Curie temperatures between $500^{\circ} \mathrm{C}$ and $530^{\circ} \mathrm{C}$. These results clearly show that the magnetic mineralogy of these samples likely consists of low-Ti magnetites. Collectively, our preliminary paleomagnetic and rock-magnetic data show that the Ninole and Kahuku Basalts are excellent recorders of the geomagnetic field, and that they will most likely yield a significant number of high-quality paleointensity results if the Thellier-Coe experiments are performed on the lavas in question. 


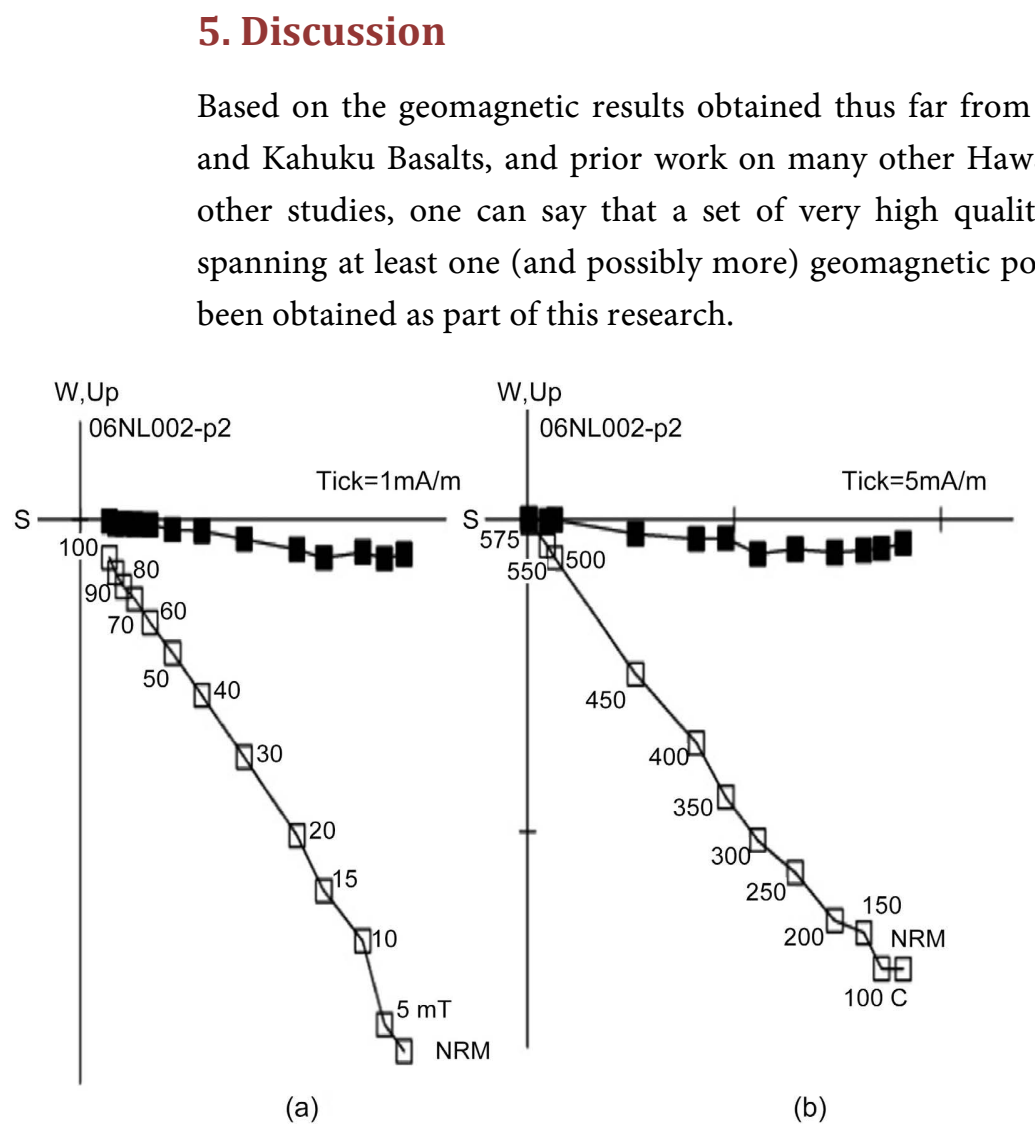

Figure 6. Example orthogonal vector plots depicting the results of alternating-field (left), and thermal (right) demagnetization experiments on Ninole Basalt samples. All samples collected from three sites for the preliminary study have straightforward and well defined components of magnetization.

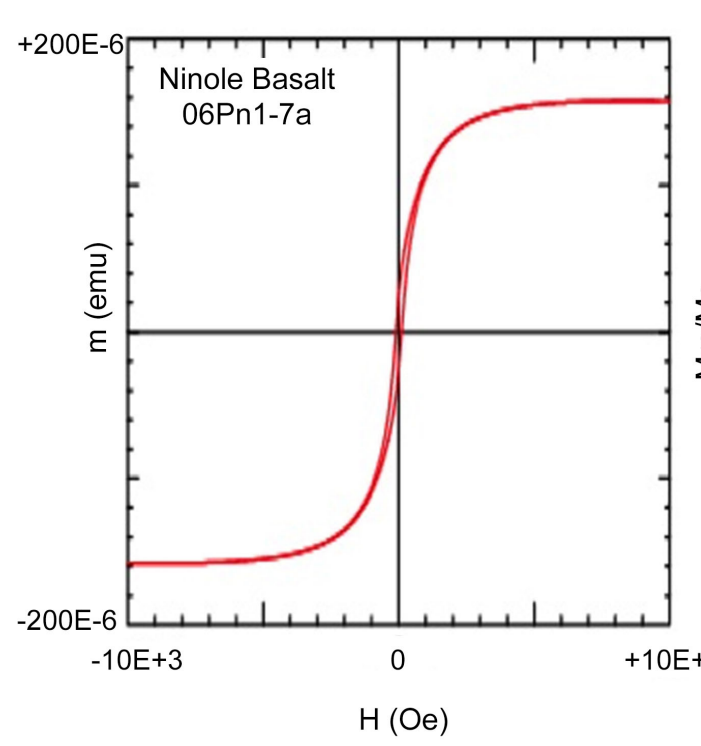

(a)

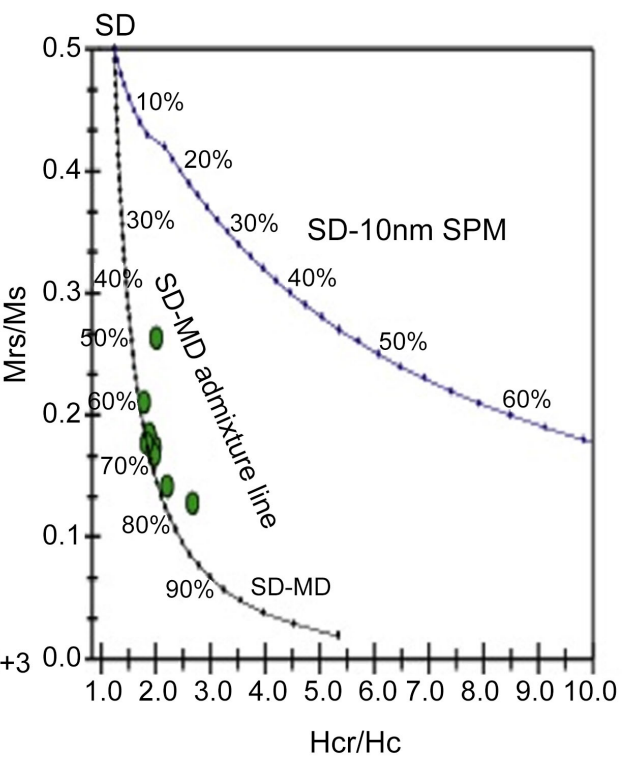

(b)

Figure 7. (a) Example hysteresis loop of Ninole Basalt sample, (b) Modified Day-type plot, showing hysteresis parameters for admixtures of SD + MD, and SD + SPM magnetites (modified from [98] Dunlop, 2002). The results for the Ninole Basalts plot in the PSD field, representing either true PSD behavior, or an admixture containing $20 \%$ to 50\% SD magnetite. 


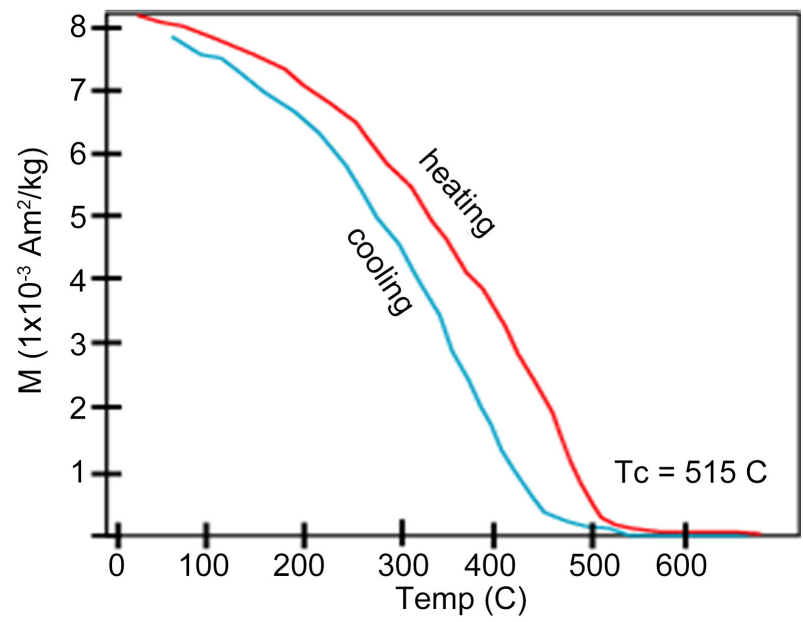

Figure 8. Example thermomagnetic curve for Ninole Basalt. Data obtained from the HIGP VFTB. This sample, as well as other samples analyzed, has simple thermomagnetic behavior, with Curie temperatures ranging from 515 to $530 \mathrm{C}$. The samples also have very good reversibility upon cooling, indicating little alteration of the magnetic mineralogy during heating and cooling experiments.
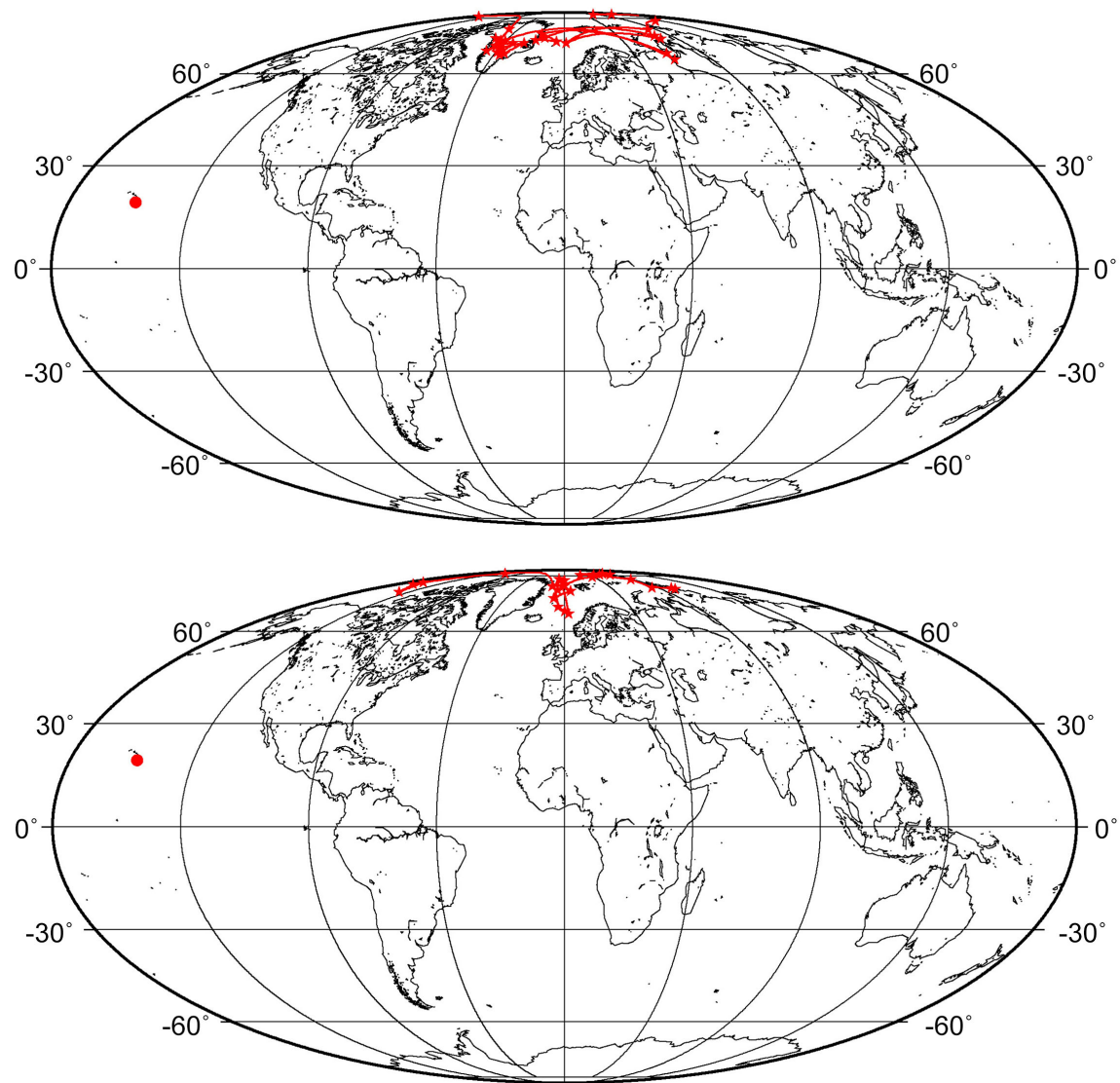

Figure 9. Virtual geomagnetic poles (VGPs) corresponding to the Kahuku and Ninole Hills volcanic series.

\section{Conclusions}

The rock magnetic experiments along with the NRM studies conducted by [60] 
demonstrate the high magnetic stability of both the Ninole and Kahuku basalts indicating the excellent reliability of both directional (i.e. declination and inclination) records.

Several of the Ninole and Kahuku Basalt flows span a geomagnetic field excursion (Figure 4 and Figure 5), and thus a combined paleomagnetic/paleointensity study of these flows will potentially yield one of the highest-resolution recordings spanning a polarity event in the future when absolute paleointensity experiments will be performed. Based on the existing age and stratigraphic relationships of both volcanic sections, the excursion found in the Ninole Basalts can be tentatively identified as the Pringle Falls excursion (ca. $211 \pm 13 \mathrm{ka}$ ). As can be seen from the magnetostratigraphic work published by [60] Doell and Cox, (1965) shown in Figure 4 and Figure 5 both the declination and inclination features can be correlated to features $C$ and perhaps B of the Pringle Falls excursion depicted in Figure 2. The same can be observed from the magnetostratigraphy diagram of the Kahuku volcanic recorded of Figure 4. There is a very sharp drop of the inclination of the top part of the younger Kahuku section that in principle could be related to the Laschamp excursion (ca. 41,000 B.P), see Figure 3. The virtual geomagnetic pole paths of both excursional records were calculated and the results are shown (see Figure 9).

The diagrams of the calculated VGPs show poles of both excursions (Laschamp and Pringle Falls) but both depict perhaps portions of truncated excursions since the VGPs are within the 62 to 90 degrees in latitude, see Figure 9.

The other unlikely possible interpretation of the Kahuku and Ninole hills basaltic flows is that the Kahuku flow corresponds to the Mono Lake excursion (ca. $\sim 32.0 \pm 2 \mathrm{ka}$ ) and Blake excursion (ca. $114 \pm 1 \mathrm{ka}$ to $120 \pm 12 \mathrm{la}$ ), Channell et al., (2020).

\section{Acknowledgements}

Funding for this research was provided by SOEST-HIGP of the University of Hawaii at Manoa. This is a SOEST contribution \#11416 and HIGP \#2450.

\section{Conflicts of Interest}

The author declares no conflicts of interest regarding the publication of this paper.

\section{References}

[1] Constable, C. (1990) Simple Statistical Model for Geomagnetic Reversals. Journal of Geophysical Research, 95, 4587-4596. https://doi.org/10.1029/JB095iB04p04587

[2] Camps, P. and Prevot, M. (1996) A Statistical Model of the Fluctuations in the Geomagnetic Field from Paleosecular Variation to Reversal. Science, 273, 776-779. https://doi.org/10.1126/science.273.5276.776

[3] Glatzmaier, G.A. and Roberts, P.H. (1995) A Three-Dimensional Convective Dynamo Solution with Rotating and Finitely Conducting Inner Core and Mantle. Physics of the Earth and Planetary Interiors, 91, 63-75. 
https://doi.org/10.1016/0031-9201(95)03049-3

[4] Glatzmaier, G.A., Coe, R.S., Hongre, L. and Roberts, P.H. (1999) The Role of the Earth's Mantle in Controlling the Frequency of Geomagnetic Reversals. Nature, 401, 885-890. https://doi.org/10.1038/44776

[5] Coe, R.S., Hongre, L. and Glatzmaier, G.A. (2000) An Examination of Simulated Geomagnetic Reversals from a Paleomagnetic Perspective. Philosophical Transactions of the Royal Society of London A, 357, 1787-1813.

[6] Johnson, C. and Constable, C. (1995) The Time-Averaged Field as Recorded by Lava Flows over the Last 5 Myrs. Geophysical Journal International, 122, 489-519. https://doi.org/10.1111/j.1365-246X.1995.tb07010.x

[7] Johnson, C. and Constable, C. (1996) Paleosecular Variation Recorded by Lava Flows over the Last 5 Myrs. Philosophical Transactions of the Royal Society of London, 354, 89-141. https://doi.org/10.1098/rsta.1996.0004

[8] Johnson, C. and Constable, C. (1997) The Time-Averaged Geomagnetic Field: Global and Regional Biases for 0-5 Ma. Geophysical Journal International, 128, 1-16. https://doi.org/10.1111/j.1365-246X.1997.tb06604.x

[9] Valet, J.-P. and Plenier, G. (2008) Simulations of a Time-Varying Non-Dipole Field during Geomagnetic Reversals and Excursions. Physics of the Earth and Planetary Interiors, 169, 178-193. https://doi.org/10.1016/j.pepi.2008.07.031

[10] Valet, J.-P. and Fournier, A. (2016) Deciphering Records of Geomagnetic Reversals. Reviews of Geophysics, 54, 410-446. https://doi.org/10.1002/2015RG000506

[11] Merrill, R.T. and McFadden, P.L. (1999) Geomagnetic Polarity Transitions. Reviews of Geophysics, 37, 201-226. https://doi.org/10.1029/1998RG900004

[12] Hoffman, K.A. and Singer, B.S. (2004) Regionally Recurrent Paleomagnetic Transitional Fields and Mantle Processes. In: Timescales of the Paleomagnetic Field, AGU Monograph Vol. 145, The American Geophysical Union, Washington DC, 233-244. https://doi.org/10.1029/145GM17

[13] Herrero-Bervera, E., Browne, E.J., Valet, J.P., Singer, B.S. and Jicha, B.R. (2007) Cryptochron C2r.2r-1 Recorded 2.51 Ma in the Koolau Volcano at Halawa, Oahu, Hawaii, USA: Paleomagnetic and ${ }^{40} \mathrm{Ar} /{ }^{39} \mathrm{Ar}$ Evidence. Earth and Planetary Science Letters, 254, 256-271. https://doi.org/10.1016/j.epsl.2006.11.023

[14] Gubbins, D. (1999) The Distinction between Geomagnetic Excursions and Reversals. Geophysical Journal International, 137, F1-F3. https://doi.org/10.1046/j.1365-246x.1999.00810.x

[15] Valet, J.-P., Laj, C. and Tucholka, P. (1986) High-Resolution Sedimentary Record of a Geomagnetic Reversal. Nature, 322, 27-32. https://doi.org/10.1038/322027a0

[16] Valet, J.-P., Laj, C. and Langereis, C.G. (1988) Sequential Geomagnetic Reversals Recorded in Upper Tortonian Marine Clays in Western Crete (Greece). Journal of Geophysical Research, 93, 1131-1151. https://doi.org/10.1029/JB093iB02p01131

[17] Valet, J.-P., Tauxe, L. and Clark, D. (1988) The Matuyama-Brunhes Transition Recorded in Lake Tecopa Sediments (California). Earth and Planetary Science Letters, 87, 463-472. https://doi.org/10.1016/0012-821X(88)90009-X

[18] Valet, J.-P., Tauxe, L. and Clement, B. (1989) Equatorial and Midlatitude Records of the Last Geomagnetic Reversal from the Atlantic Ocean. Earth and Planetary Science Letters, 94, 371-384. https://doi.org/10.1016/0012-821X(89)90154-4

[19] Valet, J.-P., Tucholka, P., Courtillot, V. and Meynadier, L. (1992) Paleomagnetic Constraints on the Geometry of the Geomagnetic Field during Reversals. Nature, 356, 400-407. https://doi.org/10.1038/356400a0 
[20] Clement, B. and Kent, D.V. (1991) A Southern Hemisphere Record of the Matuyama-Brunhes Polarity Reversal. Geophysical Research Letters, 18, 81-84. https://doi.org/10.1029/90GL02714

[21] Clement, B. (1991) Geographical Distribution of Transitional VGPs: Evidence for Nonzonal Equatorial Symmetry during the Brunhes-Matuyama Geomagnetic Reversal. Earth and Planetary Science Letters, 104, 48-58. https://doi.org/10.1016/0012-821X(91)90236-B

[22] Tric, E., Laj, C., Jehanno, C., Valet, J.-P., Kissel, C., Mazaud, A. and Iaccarino, S. (1991) High-Resolution Record of the Upper Olduvai Transition from Po Valley (Italy) Sediments; Support for Dipolar Transition Geometry? Physics of the Earth and Planetary Interiors, 65, 319-336. https://doi.org/10.1016/0031-9201(91)90138-8

[23] Tric, E., Laj, C., Valet, J.-P., Tucholka, P., Paterne, M. and Guichard, F. (1991) The Blake Geomagnetic Event; Transition Geometry, Dynamical Characteristics and Geomagnetic Significance. Earth and Planetary Science Letters, 102, 1-13. https://doi.org/10.1016/0012-821X(91)90013-8

[24] Laj, C., Mazaud, A., Weeks, R., Fuller, M.D. and Herrero-Bervera, E. (1991) Geomagnetic Reversal Paths. Nature, 351, 447. https://doi.org/10.1038/351447a0

[25] Laj, C., Mazaud, A., Weeks, R., Fuller, M. and Herrero-Bervera, E. (1992) Geomagnetic Reversal Paths [Discussion]. Nature, 359, 111-112.

https://doi.org/10.1038/359111b0

[26] Laj, C., Mazaud, A., Weeks, R., Fuller, M. and Herrero-Bervera, E. (1992) Statistical Assessment of the Preferred Longitudinal Bands for Recent Geomagnetic Field Reversal Records. Geophysical Research Letters, 19, 2003-2006.

https://doi.org/10.1029/92GL02164

[27] Van Hoof, A.A.M. and Langereis, C.G. (1992) The Upper Kaena Sedimentary Geomagnetic Reversal Record from Sicily. Journal of Geophysical Research, 97, 6941-6957. https://doi.org/10.1029/92JB00220

[28] Clement, B. and Martinson, D. (1992) A Quantitative Comparison of Two Paleomagnetic Records of the Cobb Mountain Subchron from North Atlantic Deep-Sea Sediments. Journal of Geophysical Research, 97, 1735-1752. https://doi.org/10.1029/91JB02584

[29] Herrero-Bervera, E. and Khan, M.A. (1992) Olduvai Termination; Detailed Palaeomagnetic Analysis of a North Central Pacific Core. Geophysical Journal International, 108, 535-545. https://doi.org/10.1111/j.1365-246X.1992.tb04634.x

[30] McFadden, P., Barton, C.E. and Merrill, R.T. (1993) Do Virtual Geomagnetic Poles Follow Preferred Paths during Geomagnetic Reversals? Nature, 361, 342-344. https://doi.org/10.1038/361342a0

[31] Zhu, R., Laj, C. and Mazaud, A. (1994) The Matuyama-Brunhes and Upper Jaramillo Transitions Recorded in a Loess Section at Weinan, North-Central China. Earth and Planetary Science Letters, 125, 143-158. https://doi.org/10.1016/0012-821X(94)90212-7

[32] Cisowski, S. (1995) Geomagnetic Intensity and Field Direction Changes Associated with the Matuyama/Brunhes Polarity Reversal, as Recorded in a Sediment Core from the North Pacific. Proceedings of the Ocean Drilling Program-Scientific Results, 145, 475-482. https://doi.org/10.2973/odp.proc.sr.145.151.1995

[33] Channell, J. and Lehman, B. (1997) The Last Two Geomagnetic Polarity Reversals Recorded in High-Deposition-Rate Sediment Drifts, Nature, 389, 712-715. https://doi.org/10.1038/39570

[34] Lund, S., Stoner, J.S., Channell, J.E.T. and Acton, G. (2006) A Summary of Brunhes 
Paleomagnetic Field Variability Recorded in Ocean Drilling Program Cores. Physics of the Earth and Planetary Interiors, 156, Article ID: 194-204. https://doi.org/10.1016/j.pepi.2005.10.009

[35] Valet, J.-P. and Meynadier (1993) Geomagnetic Field Intensity and Reversals during the Past Four Million Years. Nature, 366, 234-238. https://doi.org/10.1038/366234a0

[36] Channell, J.E.T., Mazaud, A., Sullivan, P., Turner, S. and Raymo, M.E. (2002) Geomagnetic Excursions and Paleointensities in the Matuyama Chron at Ocean Drilling Program Sites 983 and 984 (Iceland Basin). Journal of Geophysical Research, 107, 2001JB000491. https://doi.org/10.1029/2001JB000491

[37] Laj, C., Kissel, C. and Beer, J. (2004) High Resolution Global Paleointensity Stack since $75 \mathrm{kyr}$ (GLOPIS-75) Calibrated to Absolute Values. In: Timescales of the Paleomagnetic Field, AGU Monograph Vol. 145, The American Geophysical Union, Washington DC, 255-265. https://doi.org/10.1029/145GM19

[38] Fuller, M. (2006) Geomagnetic Field Intensity, Excursions, Reversals, and the 41,000 yr Obliquity Signal. Earth and Planetary Science Letters, 245, 605-615. https://doi.org/10.1016/j.epsl.2006.03.022

[39] Valet, J.-P., Meynadier, L. and Guyodo, Y. (2005) Geomagnetic Dipole Strength and Reversal Rate over the Past Two Million Years. Nature, 435, 802-805. https://doi.org/10.1038/nature03674

[40] Herrero-Bervera, E. and Canon-Tapia, E. (2013) On the Directional Geomagnetic Signature of the Pringle Falls Excursion Recorded at Pringle Falls, Oregon, USA, Magnetic Methods and the Timing of Geological Processes. Geological Society, London, Special Publications, 373. https://doi.org/10.1144/SP373.12

[41] Herrero-Bervera, E. and Runcorn, S.K. (1997) Transition Fields during Geomagnetic Reversals and Their Geodynamic Significance. Philosophical Transactions of the Royal Society of London A, 355, 1713-1742. https://doi.org/10.1098/rsta.1997.0089

[42] Herrero-Bervera, E. and Valet, J.-P. (2005) Absolute Paleointensity and Reversal Records from the Wai'anae Sequence (O'ahu, Hawaii USA). Earth and Planetary Science Letters, 234, 279-296. https://doi.org/10.1016/j.epsl.2005.02.032

[43] Tauxe, L. (1993) Sedimentary Records of Relative Paleointensity of the Geomagnetic Field: Theory and Practice. Reviews of Geophysics, 31, 319-354. https://doi.org/10.1029/93RG01771

[44] Lund, S. and Schwartz, M. (1996) Non-Reproducible Transition Paths within Replicate Paleomagnetic Records of the Blake Event as Recorded in Deep-Sea Sediments from the Blake/Bahama Outer Ridge (Abstract). Eos, Transactions American Geophysical Union, 77, F166.

[45] Roberts, A.P. and Winklhofer, M. (2004) Why Are Geomagnetic Excursions Not Always Recorded in Sediments? Constraints from Post-Depositional Remanent Magnetization Lock-In Modeling. Earth and Planetary Science Letters, 227, 345-359. https://doi.org/10.1016/j.epsl.2004.07.040

[46] Dunlop, D. and Özdemir, Ö. (1997) Rock Magnetism: Fundamentals and Frontiers. Cambridge Univ. Press, New York, 573 p. https://doi.org/10.1017/CBO9780511612794

[47] Riisager, J., Riisager, P., Zhao, X., Coe, R.S. and Pedersen, A.K. (2004) Paleointensity during a Chron C26r Excursion Recorded in West Greenland Lava Flows. Journal of Geophysical Research, 109, 2003JB002887. https://doi.org/10.1029/2003JB002887

[48] Tanaka, H. and Kobayashi, T. (2003) Paleomagnetism of the Late Quaternary Ontake Volcano, Japan: Directions, Intensities, and Excursions. Earth, Planets and 
Space, 55, 189-202. https://doi.org/10.1186/BF03351748

[49] Coe, R.S., Gromme, S. and Mankinen, E.A. (1984) Geomagnetic Paleointensities from Excursion Sequences in Lavas on Oahu, Hawaii. Journal of Geophysical Research, 89, 1059-1069. https://doi.org/10.1029/JB089iB02p01059

[50] Roperch, P., Bonhommet, N. and Levi, S. (1988) Paleointensity of the Earth's Magnetic Field during the Laschamp Event and Its Geomagnetic Implications. Earth and Planetary Science Letters, 88, 209-219. https://doi.org/10.1016/0012-821X(88)90058-1

[51] Chauvin, A., Duncan, R.A., Bonhommmet, N. and Levi, S. (1989) Paleointensity of the Earth's Magnetic Field and K-Ar Dating of the Louchardiere Volcanic Flow (Central France): New Evidence for the Laschamp Excursion. Geophysical Research Letters, 16, 1189-1192. https://doi.org/10.1029/GL016i010p01189

[52] Chauvin, A., Gillot, P.-Y. and Bonhommet, N. (1991) Paleointensity of the Earth's Magnetic Field Recorded by Two Late Quaternary Volcanic Sequences at the Island of La Reunion (Indian Ocean). Journal of Geophysical Research, 96, 1981-2006. https://doi.org/10.1029/90JB02223

[53] Carlut, J., Valet, J.-P., Quidellur, X., Courtillot, V., Kidane, T., Gallet, Y. and Gillot, P.-Y. (1999) Paleointensity across the Reunion Event in Ethiopia. Earth and Planetary Science Letters, 170, 17-34. https://doi.org/10.1016/S0012-821X(99)00094-1

[54] Zhu, R., Pan, Y. and Coe, R.S. (2000) Paleointensity Studies of a Lava Succession from Jilin Province, Northeastern China: Evidence for the Blake Event. Journal of Geophysical Research, 105, 8305-8317. https://doi.org/10.1029/1999JB900448

[55] Takai, A., Shibuya, H., Yoshihara, A. and Hamano, Y. (2002) Paleointensity Measurements of Pyroclastic Flow Deposits Co-Born with Widespread Tephras in Kyushu Island, Japan. Physics of the Earth and Planetary Interiors, 133, 159-179. https://doi.org/10.1016/S0031-9201(02)00090-0

[56] Herrero-Bervera, E., Helsley, C.E., Hammond, S.R. and Chitwood, L.A. (1989) A Possible Lacustrine Paleomagnetic Record of the Blake Episode from Pringle Falls, Oregon, U.S.A. Physics of the Earth and Planetary Interiors, 56, 112-123. https://doi.org/10.1016/0031-9201(89)90041-1

[57] Herrero-Bervera, E., Helsley, C.E., Sarna-Wojcicki, A.M., Lajoi, K.R., Meyer, C.E., McWilliams, M.O., Negrini, R.M., Turrin, B.D., Donelly-Nolan, J.M. and Liddicoat, J.C. (1994) Age and Correlation of a Paleomagnetic Episode in Western United States by ${ }^{40} \mathrm{Ar} /{ }^{39} \mathrm{Ar}$ Dating and Tephrachronology: The Jamaica, Blake or a New Polarity Episode? Journal of Geophysical Research, 99, 24091-24103.

https://doi.org/10.1029/94JB01546

[58] Channell, J.E.T. (2006) Late Brunhes Polarity Excursions (Mono Lake, Lachamp, Iceland Basin and Pringle Falls) Recorded at ODP Site 919 (Irminger Basin). Earth and Planetary Science Letters, 244, 378-393.

https://doi.org/10.1016/j.epsl.2006.01.021

[59] Singer, B.L., Jicha, B.R., Kirby, B.T., Zhang, X., Geissman, J.W. and Herrero-Bervera, E. (2008) ${ }^{40} \mathrm{Ar} /{ }^{39} \mathrm{Ar}$ Dating Links Albuquerque Volcanoes to the Pringle Falls and the Geomagnetic Instability Time Scale. Earth and Planetary Science Letters, 267, 584-595. https://doi.org/10.1016/j.epsl.2007.12.009

[60] Doell, R.R. and Cox, A. (1965) Paleomagnetism of Hawaiian Lava Flows. Journal of Geophysical Research, 70, 3377-3405. https://doi.org/10.1029/JZ070i014p03377

[61] Stearns, H.T. and Macdonald, G.A. (1946) Geology and Groundwater Resources on the Island of Hawaii. Hawai i Division of Hydrography Bulletins, 9, 1-363.

[62] Lipman, P.W. and Swenson, A. (1984) Generalized Geologic Map of the Southwest 
Rift Zone of Mauna Loa Volcano, Hawaii. U.S. Geological Survey Miscellaneous Investigations Map I-1323.

[63] Lipman, P.W., Rhodes, J.M. and Dalrymple, G.B. (1990) The Ninole Basalt-Implications for the Structural Evolution of Mauna Loa Volcano, Hawaii. Bulletin of Volcanology, 53, 1-19. https://doi.org/10.1007/BF00680316

[64] Lipman, P. (1995) Declining Growth of Mauna Loa during the Last 100,000 Years: Rates of Lava Accumulation vs Gravitational Subsidence, Mauna Loa Revealed: Structure, Composition, History, and Hazards, Geophysical 45-80 Monograph 92. The American Geophysical Union, Washington DC. https://doi.org/10.1029/GM092p0045

[65] Zurek, J., Williams-Jones, G., Trusdell, F. and Martin, S. (2015) The Origin of Mauna Loa's Nīnole Hills: Evidence of Rift Zone Reorganization. Geophysical Research Letters, 42, 8358-8366. https://doi.org/10.1002/2015GL065863

[66] Jicha, B.R., Rhodes, J.M., Singer, B.S. and Garcia, M.O. (2012) ${ }^{40} \mathrm{Ar} /{ }^{39} \mathrm{Ar}$ Geochronology of Submarine Mauna Loa Volcano, Hawaii. Journal of Geophysical Research, 117, B09204. https://doi.org/10.1029/2012JB009373

[67] Herrero-Bervera (2016) On the Possibility of Obtaining a High-Resolution Relative Paleointensity Record of the Pringle Falls Excursion at the Type Locality of Pringle Falls, Oregon USA. Natural Science, 8, 115-124.

https://doi.org/10.4236/ns.2016.83015

[68] Channell, J.T., Singer, B.S. and Jicha, B.R. (2020) Timming of Quaternary Geomagnetic Reversals and Excursions in Volcanic and Sedimentary Archives. Quaternary Science Reviews, 228, Article ID: 106114. https://doi.org/10.1016/j.quascirev.2019.106114

[69] Laj, C., Guillou, H. and Kissel, C. (2014) Dynamics of the Earth Magnetic Field in the 10-75 kyr Period Comprising the Laschamp and Mono Lake Excursions: New Results from the French Chaîne des Puys in a Global Perspective. Earth and Planetary Science Letters, 387, 184-197. https://doi.org/10.1016/j.epsl.2013.11.031

[70] Singer, B.S. (2014) A Quaternary Geomagnetic Instability Time Scale. Quaternary Geochronology, 21, 29-52. https://doi.org/10.1016/j.quageo.2013.10.003

[71] Bonhommet, N. and Babkine, J. (1967) Sur la presence d'aimentation inverse dans la Chaîne des Puys. Comptes rendus hebdomadaires des séances de 1 Académie des sciences Ser. B, 264, 92-94.

[72] Bonhommet, N. and Zahringer, J. (1969) Paleomagnetism and Potassium Argon Determinations of the Laschamp Geomagnetic Polarity Event. Earth and Planetary Science Letters, 6, 43-46. https://doi.org/10.1016/0012-821X(69)90159-9

[73] Guillou, H., Singer, B.S., Laj, C., Kissel, C., Scalliet, S. and Jicha, B.R. (2004) On the Age of the Laschamp Event. Earth and Planetary Science Letters, 227, 331-343. https://doi.org/10.1016/j.epsl.2004.09.018

[74] Singer, B.S., Guillou, H., Jicha, B.R., Laj, C., Kissel, C., Beard, B.L. and Johnson, C.M. (2009) ${ }^{40} \mathrm{Ar} /{ }^{39} \mathrm{Ar}, \mathrm{K}-\mathrm{Ar}$ and ${ }^{230} \mathrm{Th}-{ }^{238} \mathrm{U}$ Dating of the Laschamp Excursion: A Radioisotopic Tie-Point for Ice Core and Climate Chronologies. Earth and Planetary Science Letters, 286, 80-88. https://doi.org/10.1016/j.epsl.2009.06.030

[75] Ingham, E., Turner, G.M., Conway, C.E., Heslop, D., Roberts, A.P., Leonard, G., Townsend, D. and Calvert, A. (2017) Volcanic Records of the Laschamp Geomagnetic Excursion from Mt Ruapehu, New Zealand. Earth and Planetary Science Letters, 472, 131-141. https://doi.org/10.1016/j.epsl.2017.05.023

[76] Teanby, N., Laj, C., Gubbins, D. and Pringle, M. (2002) A Detailed Paleointensity and Inclination Record from Drill Core SOH1 on Hawaii. Physics of the Earth and 
Planetary Interiors, 131, 101-140. https://doi.org/10.1016/S0031-9201(02)00032-8

[77] Vigliotti, L., Channell, J.E.T. and Stockhecke, M. (2014) Paleomagnetism of Lake Van Sediments: Chronology and Paleoenvironment since 350 ka. Quaternary Science Reviews, 104, 18-29. https://doi.org/10.1016/j.quascirev.2014.09.028

[78] Laj, C., Kissel, C., Mazaud, A., Channell, J.E.T. and Beer, J. (2000) North Atlantic Palaeointensity Stack since $75 \mathrm{ka}$ (NAPIS-75) and the Duration of the Laschamp Event. Philosophical Transactions of the Royal Society A, 358, 1009-1025. https://doi.org/10.1098/rsta.2000.0571

[79] Laj, C., Kissel, C. and Roberts, A.P. (2006) Geomagnetic Field Behavior during the Icelandic Basin and Laschamp Geomagnetic Excursions: A Simple Transitional Field Geometry? Geochemistry, Geophysics, Geosystems, 7, Q03004. https://doi.org/10.1029/2005GC001122

[80] Lund, S.P., Acton, G.D., Clement, B., Okada, M. and Williams, T. (2001) Paleomagnetic Records of Stage 3 Excursions, Leg 172. In: Keigwin, L.D., Rio, D., Acton, G.D. and Arnold, E., Eds., Proceedings ODP Sci. Res., A\&M University College Station, Texas, 1-20. https://doi.org/10.2973/odp.proc.sr.172.217.2001

[81] Lund, S.P., Schwartz, M., Keigwin, L. and Johnson, T. (2005) Deep-Sea Sediment Records of the Laschamp Geomagnetic Field Excursion $(<41,000$ Calendar Years before Present). Journal of Geophysical Research, 110, Q12006. https://doi.org/10.1029/2003JB002943

[82] Lund, S.P., Schwartz, M. and Stott, L. (2017) Long-Term Palaeomagnetic Secular Variation and Excursions from the Western Equatorial Pacific Ocean (MIS2-4). Geophysical Journal International, 209, 587-596. https://doi.org/10.1093/gji/ggx029

[83] Evans, H.F., Channell, J.E.T., Stoner, J.S., Hillaire-Marcel, C., Wright, J.D., Neitzke, L.C. and Mountain, G.S. (2007) Paleointensity-Assisted Chronostratigraphy of Detrital Layers on the Eirik Drift (North Atlantic) since Marine Isotope Stage 11. Geochemistry, Geophysics, Geosystems, 8, Q11007. https://doi.org/10.1029/2007GC001720

[84] Channell, J.E.T., Hodell, D.A. and Curtis, J.H. (2012) ODP Site 1063 (Bermuda Rise) Revisited: Oxygen Isotopes, Excursions and Paleointensity in the Brunhes Chron. Geochemistry, Geophysics, Geosystems, 13, Q02001. https://doi.org/10.1029/2011GC003897

[85] Bourne, M., MacNiocaill, C., Thomas, A.L. and Henderson, G.M. (2013) High-Resolution Record of the Laschamp Geomagnetic Excursion at the Blake-Bahama Outer Ridge. Geophysical Journal International, 195, 1519-1533. https://doi.org/10.1093/gji/ggt327

[86] Nowaczyk, N.R., Arz, H.W., Frank, U., Kind, J. and Plessen, B. (2012) Dynamics of the Laschamp Geomagnetic Excursion from Black Sea Sediments. Earth and Planetary Science Letters, 351-352, 54-69. https://doi.org/10.1016/j.epsl.2012.06.050

[87] Yamazaki, T. and Ioka, N. (1994) Long-Term Secular Variation of the Geomagnetic Field during the Last 200 kyr Recorded in Sediment Cores from the Western Equatorial Pacific. Earth and Planetary Science Letters, 128, 527-544.

https://doi.org/10.1016/0012-821X(94)90168-6

[88] Blanchet, C.L., Thouveny, N. and de Garidel-Thoron, T. (2006) Evidence for Multiple Paleomagnetic Intensity Lows between 30 and $50 \mathrm{ka}$ BP from a Western Equatorial Pacific Sedimentary Sequence. Quaternary Science Reviews, 25, 1039-1052. https://doi.org/10.1016/j.quascirev.2005.09.001

[89] Stoner, J.S., Lund, S., Channell, J.E.T., Mix, A.C., Davies, M.H. and Lamy, F. (2008) High Sedimentation Rate Paleomagnetic Records for the Last 70 Kyrs from the Chi- 
lean Margin (ODP Sites 1233, 1234, 1235). American Geophysical Union, Fall Meeting, San Francisco, 15-19 December 2008, Abstract GP14A-02.

[90] Channell, J.E.T. and Kleiven, H.F. (2000) Geomagnetic Palaeointensities and Astrochronological Ages for the Matuyama-Brunhes Boundary and the Boundaries of the Jaramillo Subchron: Palaeomagnetic and Oxygen Isotope Records from ODP Site 983. Philosophical transactions of the Royal Society of London A, 358, 1027-1047. https://doi.org/10.1098/rsta.2000.0572

[91] Channell, J.E.T., Vazquez Riveiros, N., Gottschalk, J., Waelbroeck, C. and Skinner, L.C. (2017) Age and Duration of Laschamp and Iceland Basin Geomagnetic Excursions in the South Atlantic Ocean. Quaternary Science Reviews, 167, 1-13. https://doi.org/10.1016/j.quascirev.2017.04.020

[92] Collins, L.G., Hounslow, M.W., Allen, C.S., Hodgson, D.A., Pike, J. and Karloukovski, V.V. (2012) Palaeomagnetic and Biostratigraphic Dating of Marine Sediments from the Scotia Sea, Antarctica: First Identification of the Laschamp Excursion in the Southern Ocean. Quaternary Geochronology, 7, 67-75.

https://doi.org/10.1016/j.quageo.2011.10.002

[93] Mazaud, A., Sicre, M.A., Ezat, U., Pichon, J.J., Duprat, J., Laj, K.C., Beaufort, L., Michel, E. and Turon, J.L. (2002) Geomagnetic-Assisted Stratigraphy and Sea Surface Temperature Changes in Core MD94-103 (Southern Indian Ocean): Possible Implications for North-South Climatic Relationships around H4. Earth and Planetary Science Letters, 201, 159-170. https://doi.org/10.1016/S0012-821X(02)00662-3

[94] Lascu, I., Feinberg, J.M., Dorale, J.A., Cheng, H. and Edwards, R.L. (2016) Age of the Laschamp Excursion Determined by U-Th Dating of a Speleothem Geomagnetic Record from North America. Geology, 44, 139-142. https://doi.org/10.1130/G37490.1

[95] Holt, J.W. and Kirschvink, J.L. (1996) Geomagnetic Field Inclination for the Past $400 \mathrm{kyr}$ from the 1-km Core of the Hawaii Scientific Drilling Project. Journal of Geophysical Research, 101, 11655-11663. https://doi.org/10.1029/95JB03843

[96] Laj, C. and Kissel, C. (1999) Geomagnetic Field Intensity at Hawaii for the Last 420 Kyr from the Hawaii Scientific Drilling Project Core, Big Island, Hawaii. Journal of Geophysical Research, 104, 15317-15338. https://doi.org/10.1029/1999JB900113

[97] Day, R., Fuller, M. and Schmidt, V.A. (1977) Hysteresis Properties of Titanomagnetites: Grain-Size and Compositional Dependence. Physics of the Earth and Planetary Interiors, 13, 260-266. https://doi.org/10.1016/0031-9201(77)90108-X

[98] Dunlop, D.J. (2002) Theory and Application of the Day Plot (Mrs/Ms versus $\mathrm{Hcr} / \mathrm{Hc}$ ) 1. Theoretical Curves and Tests Using Titanomagnetite. Journal of Geophysical Research, 107, EPM 4-1-EPM 4-22. https://doi.org/10.1029/2001JB000486 